\title{
In Vitro Regeneration of Sugar Palm (Arenga pinnata Wurmb Merr.)
}

\author{
Nazatul Asikin Muda ${ }^{\# 1}$, Asmah Awal ${ }^{* 2}$, Nor Azma Yusuf ${ }^{* 3}$, Mohd Yusoff Abdullah ${ }^{\# 4}$

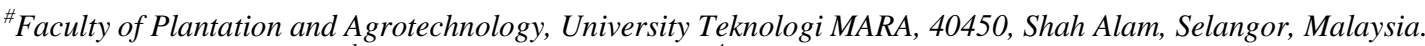 \\ E-mail: ' naza_asyiq87@yahoo.com; ${ }^{4}$ yusoff_abdullah@salam.uitm.edu.my \\ *Agricultural Biotechnology Research Group, Faculty of Plantation and Agrotechnology, Universiti Teknologi MARA, 40450, \\ Shah Alam, Selangor, Malaysia. \\ E-mail: ${ }^{2}$ asmah138@salam.uitm.edu.my; ${ }^{3}$ azma_yusuf@salam.uitm.edu.my
}

\begin{abstract}
Optimization of a protocol for in vitro regeneration of sugar palm (Arenga pinnata Wurmb Merr.) by direct organogenesis using the immature zygotic embryo and basal stem explants of in vitro raised seedlings has been developed. The explants were cultured on MS medium supplemented with different concentrations of PGRs, and the organogenic capability of the explants was investigated. Both explants were responsive, but the results were greatly dependent on the genotype and the culture medium composition investigated. After 8 weeks of culture, basal stem explant cultured on MS + 1.0 mg/L Kin + 2.0 mg/L NAA promoted optimum response for direct organogenesis $(90 \%)$ with a total of 9 adventitious shoots and 25 roots. Subculturing of individual shoots in basal MS medium (MS0) optimized further development. Meanwhile, immature zygotic embryo explant cultured on MS + 2.0 $\mathrm{mg} / \mathrm{L}$ BAP $+2.0 \mathrm{mg} / \mathrm{L}$ NAA promoted optimum root regeneration $(70 \%)$, though $\mathrm{MS}$ medium containing $2.0 \mathrm{mg} / \mathrm{L} \mathrm{BAP}+1.0 \mathrm{mg} / \mathrm{L}$ GA3 and $1.0 \mathrm{mg} / \mathrm{L} \mathrm{AgNO3}$ promoted optimum shoots growth (total of 10 shoots) at the rate of $0.04 \%$. In vitro rooting of the regenerated shoots was successfully obtained on MS + 3.0 mg/L IBA. Established in vitro plantlets with roots were hardened in soil: peat moss: perlite (2:2:1) mixture. Acclimatization of plantlets was successfully obtained with $70 \%$ seedlings survived after 4 month's exposures under the light intensity of 50-100 $\mu \mathrm{mol} \mathrm{m-2s-1.}$
\end{abstract}

Keywords—acclimatization; basal stem explant; light intensity; plant growth regulators (PGRs).

\section{INTRODUCTION}

Palm (Arecaceae) is one of the renowned and expansively planted plant families in the world. In the areas where they are habitually found, palms feature as a unique component of a landscape for their exotic appearances aside from being significantly important for the economic establishment and the surrounding ecosystem [1]. Throughout history, human has been utilizing palms as a source of foods and many trivial products. Many trees with a great economic importance such as date palm, coconut palm, oil palm, rattan palm, and beetle nut belong to the palm family. One of the famous genera in the palm family is the genus Arenga. Genus Arenga consisted of 24 palm species which includes sugar palm (Arenga pinnata Wurmb Merr.); a palm species which is widely planted for its high yield sugary sap and industrially valuable black fibers.

The current study was thus performed aimed to examine the in vitro regeneration potential of the palm species (sugar palm). The earliest and the largest population of sugar palm was said to be found in the rural regions of North East Asia, Indonesia, Malaysia, Myanmar, Philippines, and Thailand ([2], [3]). Depending on the regions they usually occur, sugar palm is also commonly known as 'areng palm,' 'kabung,' black sugar palm and toddy palm. Its high yield sugary sap is highly demanded by the locals as a food sweetener and as the source of alcohol and bioethanol.

Meanwhile, the black fibers which are extracted from the tree are industrially demanded as ship cordages due to its high durability and resistance to seawater [4]. Other byproducts such as seeds, leaves, petioles, and trunks are used in basketry and carpentry works. Eventually, there have been several limitations reported with regards to the development and vegetative propagation of sugar palm trees. In its origin, sugar palm trees are generally propagated from mature seeds. However, the germinated seeds frequently produced non-homogenous seedlings with low viability and poor field growth [5]. In open storage, sugar palm's seeds can be stored for at most 3 months, and the percentage of seeds survived was very low. Seed dormancy and recalcitrant seeds are another greatest concern in the propagation process of sugar palm [6].

In vitro regeneration can be defined as the method of growing or maintaining plant cells, tissues, or organs under the aseptic condition on an artificial nutrient medium [7]. For many plant species; such as forest trees which are difficult to be propagated through conventional method, the 
in vitro regeneration method through plant tissue culture technology serves as an efficient breeding system due to its high multiplication rate. The elite genotypes can be clonally propagated in masses providing uniform and sterile seedlings. The widespread practices of plant tissue culture technology and its significant contribution at both agriculture and industrial levels have thus established it as an essential tool in modern agriculture [8]. Additionally, the technique also serves as an alternative solution to overcome the low germination rate of many important plant species, including palms in their natural habitat [9]. Plant tissue culture medium incorporated with small concentrations of plant growth regulators (PGRs) would greatly influence the whole plant processes, which include growth and morphogenesis. The relative amounts of PGRs such as auxins to cytokinins are important in determining whether cultures develop shoots (high cytokinin + auxin ration), roots (low cytokinin + auxin ratio) or calluses as a result from the relatively high levels of cytokinin-to-auxin ratio [10].

Work on plant tissue culture studies in sugar pal, including direct organogenesis, is still lacking or the actual stage. Some reports are available on in vitro studies of sugar palm ([6], [11], [12]), but the number of shoots regenerated, in vitro / ex vitro rooting, acclimatization and the percentage of in vitro raised seedlings under field conditions were very limited. Hence, the current study described standardized protocols for clonal micro propagation of sugar palm by direct organogenesis using immature zygotic embryos and basal stem cuttings of in vitro seedlings as explant. In vitro rooting and the plantlets development during ex vitro acclimatization influenced by different potting substrate mixtures and light intensity for field transfer of this species were also investigated. The established protocols can be useful for obtaining true-to-type sugar palm plants at a commercial scale to conserve its germplasm and particularly essential for the establishment of genetic transformation studies through biotechnological interventions.

\section{MATERIALS AND METHODS}

\section{A. Plant Materials}

All experiments were performed at the Postgraduate Plant Tissue Culture Laboratory, Faculty of Plantation and Agrotechnology, Universiti Teknologi MARA (UiTM), Puncak Alam, Selangor, Malaysia during 2014-2015. Fresh fruits of sugar palm were collected from a selected grower in Pahang state, Malaysia. Mature fruits at the range size of 5.0-5.5 $\mathrm{cm}$ were selected and washed with tap water to remove dirt on the outer coats of the fruits. Surface sterilization method was carried out by soaking the fruits in $70 \%$ ethyl alcohol (C2H6O) for 30 minutes and rinsed with sterile distilled water given three changes. The fruits were later soaked in $50 \%$ sodium hypochlorite $(\mathrm{NaOCl})$ added with a few drops of Tween 20 for yet another 30 minutes. After another three rinses with sterile distilled water, the sterilized fruits were left to dry in a laminar air flow cabinet (BioBase, BBS-V18000) before immature zygotic embryos excision.

\section{B. In Vitro Germination of Sugar palm and Selection of Explants}

To obtain the in vitro seedlings of sugar palm (Fig. 2a), excised immature zygotic embryos were cultured on basal MS [13] medium consisted of $4.41 \mathrm{~g} / \mathrm{L}$ MS salt, $30.0 \mathrm{~g} / \mathrm{L}$ sucrose and $2.5 \mathrm{~g} / \mathrm{L}$ gelrite. Prepared media ( $\mathrm{pH}$ 5.8) were autoclaved at $121^{\circ} \mathrm{C}$ for 20 minutes. Cultures were incubated at $25 \pm 2^{\circ} \mathrm{C}$ and $16 / 8 \mathrm{~h}$ photoperiod for a few months or until the seedlings were established. The in vitro seedlings were later used as source of basal stem explant. Basal stem segments excised approximately at $0.5 \mathrm{~cm}$ length were used as explant (Fig. 3a).

\section{Direct Organogenesis of Explants and Culture Conditions}

Immature zygotic embryo and basal stem explants were cultured on MS medium supplemented with different concentrations of PGRs mainly benzyl-amino purine-acid (BAP), gibberellin $\left(\mathrm{GA}_{3}\right)$, kinetin (Kin) and naphthaleneacetic-acid (NAA) to obtain direct organogenesis in sugar palm. The PGRs involved were being tested separately or in combinations. Basal MS medium served as a control treatment. The cultures were later maintained under continuous white fluorescent light at the temperature of $25 \pm 2^{\circ} \mathrm{C}$ at $16 / 8 \mathrm{~h}$ photoperiod. Subculture was performed at 4 week-intervals.

\section{In Vitro Rooting}

Regenerated shoots were rooted in vitro on the MS medium containing 1.0-2.0 mg/L NAA, indole-3-acetic acid (IAA) and indole-3-butyric acid (IBA). MS0 served as a control treatment. All shoots were incubated separately on the rooting medium and maintained in a growth chamber at $25 \pm 2{ }^{\circ} \mathrm{C}$ and $16 / 8 \mathrm{~h}$ photoperiod for 4 weeks. After 5-12 consecutive weeks, the growth parameters of in vitro rooting frequency $(\%)$, number of roots, root length $(\mathrm{cm})$, and the number of leaf per culture were recorded.

\section{E. Acclimatization of In Vitro Plantlets}

In vitro plantlets with well-developed roots and having 12 fully expanded leaves (Fig. 5b) were deflasked and washed to remove adhering agar. Plantlets were dipped in fungicide solution and transferred to plastic pots half-filled with sterile soil: peat moss: perlite $(2: 2: 1)$ mixture. To maintain high humidity, the plastic pots were sealed with translucent plastic sheets. The pots were then placed in a growth room under controlled condition, the plastic covers were gradually removed after 15 days and completely removed after 3 months. Acclimatized plantlets were later transplanted to new planting pots filled with normal garden soil and left exposed under $<50,50-100$ and $>100 \mu \mathrm{mol} \mathrm{m} \mathrm{m}^{-2} \mathrm{~s}^{-1}$ light intensities at $16 / 8 \mathrm{~h}$ photoperiod light was provided by fluorescent lamp (Philips CFL Tornado). The light intensity at the plant level was adjusted by changing the plants' distance to the light source. The growth chamber was covered with a black cloth to reduce errors due to external light source. The temperature was kept constant at $25 \pm 2^{\circ} \mathrm{C}$ to ensure that the differences of light intensities mainly influenced the result. Fertigation was supplied by a sprayer once every two days of acclimatization. The response of plantlets' growth during acclimatization process was indicated by the parameters of the percentage of plantlets survived $(\%)$, plant height $(\mathrm{cm})$, stem girth $(\mathrm{cm})$, number of 
leaves and its width $(\mathrm{cm})$. Results were recorded after 4 months.

\section{F. Statistical Analysis}

The in vitro regeneration experiments were performed as in Completely Randomized Design (CRD), while the acclimatization experiment was laid out as in Randomized Complete Block Design (RCBD). Each treatment was replicated 10 times and each experiment was conducted twice. Analysis of data was statistically evaluated using the Statistical Package for the Social Science (SPSS) software. The significant of differences between treatments were evaluated using the analysis of variance (ANOVA) followed by Tukey's range post-hoc test at 0.05 level of significance.

\section{RESULT AND DISCUSSION}

\section{A. In Vitro Regeneration of Sugar Palm by Direct Organogenesis}

The morphogenesis response on in vitro regeneration of sugar palm using the basal stem and immature zygotic embryo explants was evaluated. The rate of organogenesis (\%) (Fig. 1) and the total number of regenerated shoots or roots or both for each culture were determined as growth parameters. Data was recorded after 4 and 8 weeks following inoculations. Results obtained from both explants were compared to conclude the best explants for direct organogenesis response in sugar palm.

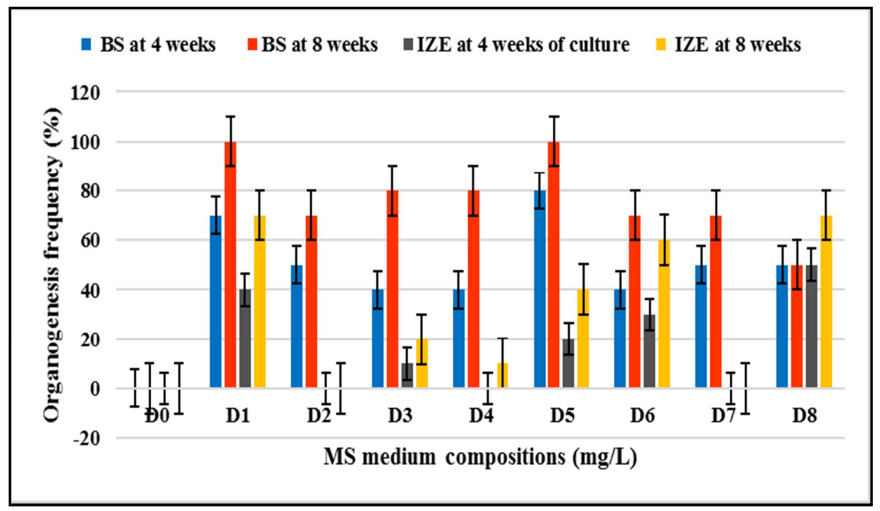

Fig. 1 Organogenesis frequency (\%) of sugar palm from basal stem explant (BS) and immature zygotic embryo explant (IZE) on different MS medium compositions (mg/L) after 4 and 8 weeks of culture. MS medium compositions (D0-D8), refer to Table 1. Organogenesis frequency $(\%)=$ Explants inducing shoot or root / total explants) x 100. Error bars indicated the standard error (SE) of the mean of 10 replication.

1) Immature Zygotic Embryo Explant: When evaluating the performance of immature zygotic embryo explant for direct organogenesis, the morphogenic response obtained from each culture medium was the formation of adventitious roots and shoots. Based on a few series of preliminary study conducted, a typical generation response of zygotic embryo culture in sugar palm occurred in four phases, i.e. (a) swollen of zygotic embryo, (b) development and elongation of cotyledonary petiole / sheath, (c) development of primary and adventitious roots from the cotyledonary petiole tips, and (d) the establishment of shoot from the sheath's cleft. These phases are the general development process of immature zygotic embryo explant being cultured on basal MS medium. Upon addition of PGRs to the culture medium, rapid growth of adventitious roots which mostly formed directly at the base of a swollen embryo was the first to be identified (Fig. 2b). The morphogenesis process took place as early as 2-4 weeks following culture and accelerated thereafter.
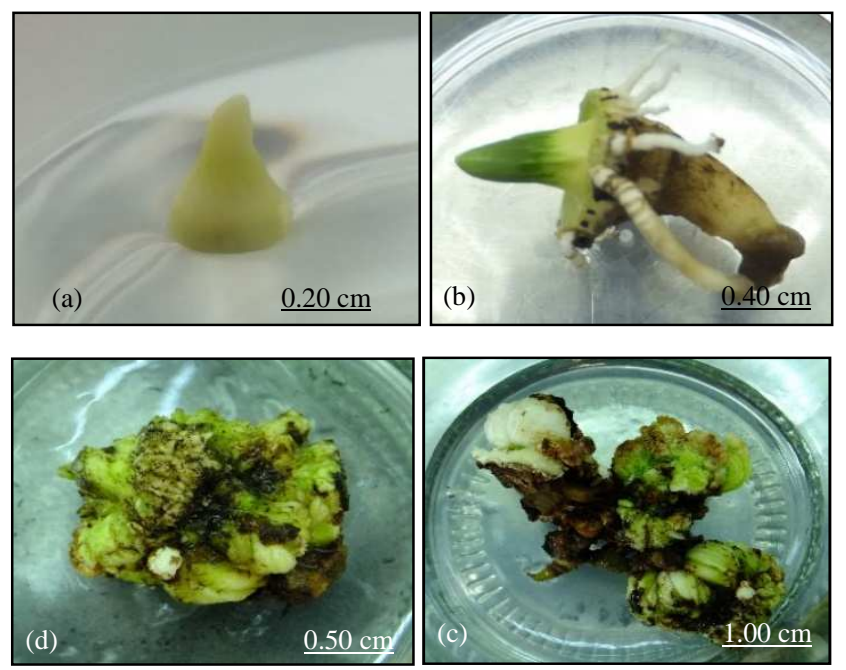

Fig. 2 The morphogenesis of in vitro regeneration of sugar palm from zygotic embryo explant after (a) 2 weeks of culture, (b) clonal roots regeneration after 4-6 weeks, and (c-d) multiple clonal shoots regeneration with bud-like appearance after 3 months on optimum MS medium supplemented with $1.0 \mathrm{mg} / \mathrm{L} \mathrm{BAP}+1.0 \mathrm{mg} / \mathrm{l} \mathrm{NAA}+1.0 \mathrm{mg} / \mathrm{L} \mathrm{AgNO}_{3}$.

In the present study, an optimum root organogenesis response from the immature zygotic embryo explant was observed on MS medium supplemented with $1.0 \mathrm{mg} / \mathrm{L}$ BAP and $1.0 \mathrm{mg} / \mathrm{L} \mathrm{NAA}$ with $70 \%$ rate of regeneration and a total of 4-14 roots after 4-8 weeks of culture, while MS medium added with IAA in combinations with either Kin and BAP gave response to $20-70 \%$ rate of regeneration and a total of 1-5 roots per culture. MS medium containing $2.0 \mathrm{mg} / \mathrm{L} \mathrm{BAP}$ and $1.0 \mathrm{mg} / \mathrm{L} \mathrm{GA}$ gave similar response followed with a single shoot development (Table I).

TABLE I

PGRS RESPONSE ON IN VITRO REGENERATION OF IMMATURE ZYGOTIC EMbryo EXPlant In Sugar PALM By DiReCt ORGanOgENESIS AFTER 4 AND 8 WEEKS OF CULTURE

\begin{tabular}{|c|c|c|c|c|c|}
\hline \multirow[t]{2}{*}{ * } & \multirow{2}{*}{$\begin{array}{l}\text { MS medium } \\
\text { composition (s) }\end{array}$} & \multicolumn{2}{|c|}{4 weeks } & \multicolumn{2}{|c|}{8 weeks } \\
\hline & & $\begin{array}{c}\text { Roots } \\
\text { per } \\
\text { culture }\end{array}$ & $\begin{array}{c}\text { Shoots } \\
\text { per } \\
\text { culture }\end{array}$ & $\begin{array}{c}\text { Roots } \\
\text { per } \\
\text { culture }\end{array}$ & $\begin{array}{c}\text { Shoots } \\
\text { per } \\
\text { culture }\end{array}$ \\
\hline D0 & MS0 & Nil & Nil & Nil & Nil \\
\hline D1 & $\begin{array}{l}\mathrm{MS}+1.0 \mathrm{mg} / \mathrm{L} \text { BAP } \\
+1.0 \mathrm{mg} / \mathrm{L} \mathrm{NAA}\end{array}$ & 4 & Nil & 14 & Nil \\
\hline D2 & $\begin{array}{l}\mathrm{MS}+2.0 \mathrm{mg} / \mathrm{L} \mathrm{BAP} \\
+1.0 \mathrm{mg} / \mathrm{L} \mathrm{NAA}\end{array}$ & Nil & Nil & Nil & Nil \\
\hline D3 & $\begin{array}{l}\mathrm{MS}+1.0 \mathrm{mg} / \mathrm{L} \text { BAP } \\
+1.0 \mathrm{mg} / \mathrm{L} \text { IAA }\end{array}$ & 1 & Nil & 2 & Nil \\
\hline D4 & $\begin{array}{l}\mathrm{MS}+2.0 \mathrm{mg} / \mathrm{L} \mathrm{BAP} \\
+1.0 \mathrm{mg} / \mathrm{L} \text { IAA }\end{array}$ & Nil & Nil & Nil & Nil \\
\hline D5 & $\begin{array}{l}\mathrm{MS}+1.0 \mathrm{mg} / \mathrm{L} \mathrm{Kin} \\
+1.0 \mathrm{mg} / \mathrm{L} \text { IAA }\end{array}$ & 2 & Nil & 5 & Nil \\
\hline D6 & $\begin{array}{l}\mathrm{MS}+2.0 \mathrm{mg} / \mathrm{L} \mathrm{Kin} \\
+1.0 \mathrm{mg} / \mathrm{L} \text { IAA }\end{array}$ & Nil & Nil & Nil & Nil \\
\hline D7 & $\begin{array}{l}\mathrm{MS}+1.0 \mathrm{mg} / \mathrm{L} \mathrm{BAP} \\
+1.0 \mathrm{mg} / \mathrm{L} \mathrm{GA} 3\end{array}$ & Nil & Nil & Nil & Nil \\
\hline D8 & $\begin{array}{l}\mathrm{MS}+2.0 \mathrm{mg} / \mathrm{L} \mathrm{BAP} \\
+1.0 \mathrm{mg} / \mathrm{L} \mathrm{GA}_{3}\end{array}$ & 1 & Nil & 4 & Nil \\
\hline
\end{tabular}

*Treatment; Sample size $(\mathrm{N})=10$ 
Organogenesis was not presented on the control treatment (MS0) and as well as on the remaining medium treatments. Shoot multiplication was also unavailable in all treatments tested. Repeating the experiment using the similar set of MS media compositions and supplemented with silver nitrate $\left(\mathrm{AgNO}_{3}\right)$ at $1.0 \mathrm{mg} / \mathrm{L}$ concentration had favorably induced adventitious shoots formation in sugar palm using immature zygotic embryo explant (Fig. 2c). After 16 weeks in culture, a total of 10 shoots was recorded on MS medium supplemented with $2.0 \mathrm{mg} / \mathrm{L}$ BAP, $1.0 \mathrm{mg} / \mathrm{L} \mathrm{GA}_{3}$ and 1.0 $\mathrm{mg} / \mathrm{L} \mathrm{AgNO}_{3}$; though the regeneration percentage was relatively low at $0.04 \%$, concluded to the great dependence of PGRs and genotype to the direct organogenesis of sugar palm from this explant. This finding is consistent with the result reported in date palm where $\mathrm{AgNO}_{3}$ have been used in accordance to auxin/cytokinin to obtain shoot multiplication [14]. The induced shoots were incomplete with bud-like structure and green in color. During induction stage, the shoots remained attached to the explant in clumps and inseparable from each other. The structure remained for 15 weeks following detachment and separately cultured on MS0 (Fig. 2d) for further development. However, these shoots showed poor elongation as well as rooting on the MS culture medium in absence of PGRs. This condition persisted for yet another 6 months.

2) Basal Stem Explant: Meanwhile, the organogenesis response from basal stem explant was determined after 2-4 weeks of culture on MS medium containing different concentrations of PGRs. After 4-8 weeks, the highest yield of adventitious shoots formation in sugar palm using basal stem explant was observed on $\mathrm{MS}+1.0 \mathrm{mg} / \mathrm{L} \mathrm{Kin}+1.0$ $\mathrm{mg} / \mathrm{L}$ IAA with $80-100 \%$ rate of organogenesis and 15-25 roots regeneration. The optimum shoot regeneration was instead recorded from the explant cultured on $\mathrm{MS}+1.0$ $\mathrm{mg} / \mathrm{L} \mathrm{BAP}+1.0 \mathrm{mg} / \mathrm{L} \mathrm{NAA}$ and $\mathrm{MS}+2.0 \mathrm{mg} / \mathrm{L} \mathrm{BAP}+1.0$ $\mathrm{mg} / \mathrm{l} \mathrm{GA}{ }_{3}$ with a total of 7-10 per culture (Table II).

\section{TABLE II}

PGRS RESPONSE ON IN VITRO REGENERATION OF BASAL STEM Explant Obtained From IN Vitro SeEdling of Sugar Palm by Direct ORganogenesis AFTER 4 AND 8 WeEKS OF CUlture

\begin{tabular}{|c|l|c|c|c|c|}
\hline$*$ & \multirow{2}{*}{$\begin{array}{l}\text { MS medium } \\
\text { composition (s) }\end{array}$} & $\begin{array}{c}\text { 4 weeks } \\
\text { per } \\
\text { culture }\end{array}$ & $\begin{array}{c}\text { Shoots } \\
\text { per } \\
\text { culture }\end{array}$ & $\begin{array}{c}\text { Roots } \\
\text { per } \\
\text { culture }\end{array}$ & $\begin{array}{c}\text { Shoots } \\
\text { per } \\
\text { culture }\end{array}$ \\
\hline D0 & MS0 & Nil & Nil & Nil & Nil \\
\hline D1 & $\begin{array}{l}\text { MS + 1.0 mg/L BAP + } \\
1.0 \mathrm{mg} / \mathrm{L} \mathrm{NAA}\end{array}$ & Nil & 7 & Nil & 10 \\
\hline D2 & $\begin{array}{l}\text { MS + 2.0 mg/L BAP + } \\
1.0 \mathrm{mg} / \mathrm{L} \mathrm{NAA}\end{array}$ & Nil & 5 & Nil & 7 \\
\hline D3 & $\begin{array}{l}\text { MS + 1.0 mg/L BAP + } \\
1.0 \mathrm{mg} / \mathrm{L} \mathrm{IAA}\end{array}$ & Nil & Nil & Nil & Nil \\
\hline D4 & $\begin{array}{l}\text { MS + 2.0 mg/L BAP + } \\
1.0 \mathrm{mg} / \mathrm{L} \mathrm{IAA}\end{array}$ & 3 & Nil & 10 & Nil \\
\hline D5 & $\begin{array}{l}\text { MS + 1.0 mg/L Kin + } \\
1.0 \mathrm{mg} / \mathrm{L} \mathrm{IAA}\end{array}$ & 15 & 5 & 25 & 9 \\
\hline D6 & $\begin{array}{l}\text { MS + 2.0 mg/L Kin + } \\
1.0 \mathrm{mg} / \mathrm{L} \mathrm{IAA}\end{array}$ & Nil & 4 & Nil & 7 \\
\hline D7 & $\begin{array}{l}\text { MS + 1.0 mg/L BAP + } \\
1.0 \mathrm{mg} / \mathrm{L} \mathrm{GA}\end{array}$ & 9 & 5 & 11 & 7 \\
\hline D8 & $\begin{array}{l}\text { MS + 2.0 mg/L BAP + } \\
1.0 \mathrm{mg} / \mathrm{L} \mathrm{GA}\end{array}$ & Nil & 8 & Nil & 10 \\
\hline
\end{tabular}

*Treatment; Sample size $(\mathrm{N})=10$
Depending to the composition of PGRs, the regeneration of clonal plantlets started with the elongation of primordial structures as early as 1 week after culture, which then gradually formed into single shoots within 4 weeks of induction stage (Fig. 3b-3c). These shoots later developed leaves and in some treatments, roots (Fig. 3d). Multiplication of shoots were not obtainable on all treatments tested. The established shoots were yellowish green or green in color and turned to dark green as the leaves developed. Subculture of explants for the second time onto similar MS medium composition resulted in another single shoot regeneration (Fig. 3e). However it took 12 weeks for the regeneration to occur.

Upon transferring the regenerants on MS0 or $1 / 2$ strength MS0, it takes an approximate of 5-7 months for the shoots to elongate (Fig. 3f). The process was very slow and the condition remained for over a year with no further development suggesting dormancy. Adventitious roots at 0.2 $\mathrm{cm}$ were identified after 7 months of subculture. After 15 months, the regenerated shoots showed necrosis and deteriorated.
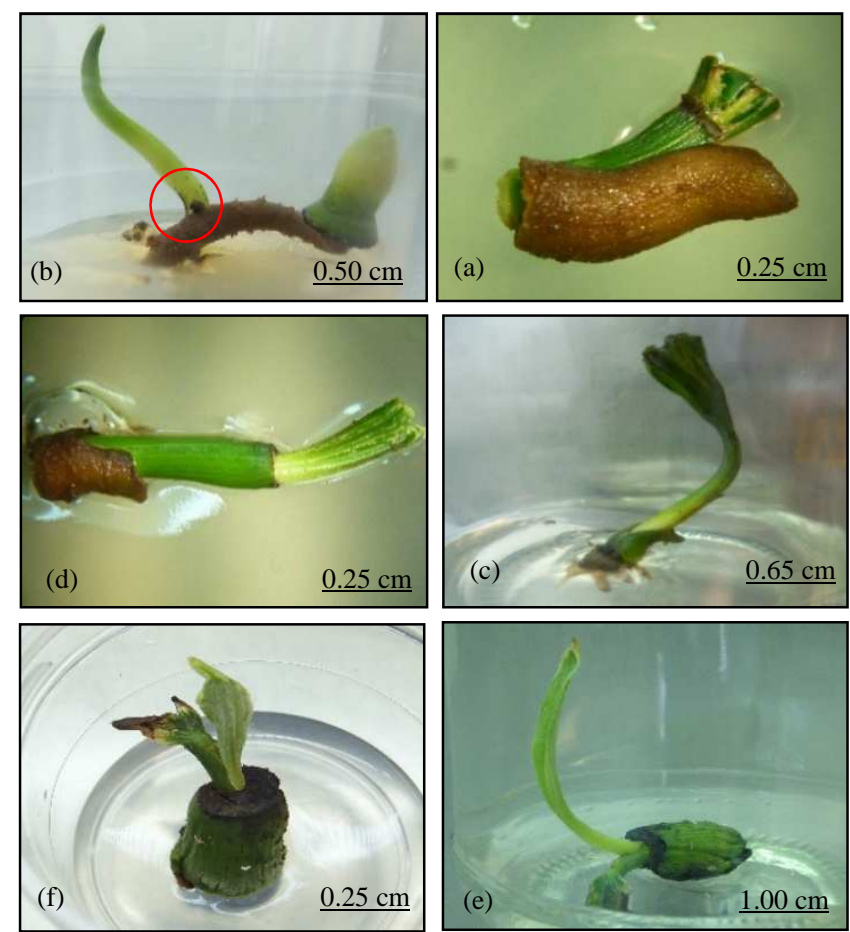

Fig. 3 selection of basal stem explant from (a) in vitro seedling of sugar palm (circle). (b) Elongation of primordial structure from explant after 2 weeks of culture, (e) a single shoot regeneration after 4 weeks. (d) Complete plantlet with an established shoot forming leaves and roots formation after $\mathrm{S}$ weeks of culture on optimum MS culture medium. (e) Formation of a single shoot from basal stem explant during second subculture on MSO after (e) 5 months and (f) 12 months.

Comparing the organogenesis response between the immature zygotic embryo and basal stem explants, it was thus concluded that basal stem explant obtained from in vitro seedling was efficient for the in vitro regeneration of sugar palm by direct organogenesis, depending to the genotype and PGRs used. In vitro regeneration of plants using nodal parts or basal stem segments are the most commonly reported for many plant species with high chance of success [15] - 17]. However, it was the efficient use of PGRs to the 
culture medium which plays an important role to determine success of a plant micropropagation process. PGRs in a culture medium are vital to regulate growth, development and responses to stimuli in a plant system. Depending on the plant requirement and desired result, different types of PGRs are used for specific types of plants [18-[20]. In this study, it was determined that, the addition of PGRs mainly BAP, $\mathrm{GA}_{3}$ and $\mathrm{AgNO}_{3}$ had promoted shoots formation of explants via direct organogenesis and significantly improved the shoots growth and roots formation in culture.

\section{B. In Vitro Rooting of Clonal Sugar Palm Plantlets}

Established plantlets from basal stem explant with poor or no roots were transferred to MS rooting medium consisted of four levels of PGRs compositions prior to acclimatization. Shoots with developed roots were obtained after 5-12 weeks of culture (Fig. 4).

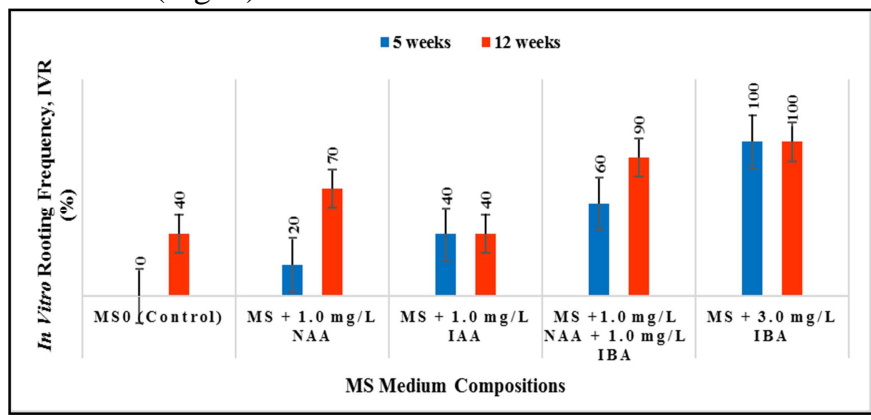

Fig. 4 In vitro rooting frequency (IVR, \%) of sugar palm on different MS medium compositions after 5 and 12 weeks of culture. (IVR, $\%=$ Explants inducing shoot or root / total explants $\mathrm{x} 100)$. Error bars indicate the standard error (SE) of the mean of 10 replicates.

From the experiment, it was observed that among the treatments tested, MS medium containing IBA was found most effective than NAA and IAA for optimum in vitro rooting response of clonal sugar palm shoots from basal stem explant (Table III and Table IV).

TABLE III

PGRS RESPONSE ON IN VITRO ROOTING OF IN VITRO PLANTLETS ObTAINED FROM BASAL STEM EXPLANT OF SUGAR PALM By DiRECT ORGANOGENESIS AFTER 5 WEEKS OF CULTURE

\begin{tabular}{|l|c|c|c|}
\hline $\begin{array}{l}\text { MS medium } \\
\text { composition (s) }\end{array}$ & $\begin{array}{c}\text { Roots per } \\
\text { culture }\end{array}$ & $\begin{array}{c}\text { Root length } \\
\text { per culture } \\
(\mathbf{c m})\end{array}$ & $\begin{array}{c}\text { Leaf per } \\
\text { culture }\end{array}$ \\
\hline $\mathrm{MS} 0$ & $0.00 \pm 0.00^{\mathrm{a}}$ & $0.00 \pm 0.00^{\mathrm{a}}$ & $1.20 \pm 0.20^{\mathrm{a}}$ \\
\hline $\mathrm{MS}+1.0 \mathrm{mg} / \mathrm{L} \mathrm{NAA}$ & $1.40 \pm 0.25^{\mathrm{ab}}$ & $1.50 \pm 0.22^{\mathrm{bc}}$ & $1.00 \pm 0.00^{\mathrm{a}}$ \\
\hline $\mathrm{MS}+1.0 \mathrm{mg} / \mathrm{L} \mathrm{IAA}$ & $0.60 \pm 0.40^{\mathrm{a}}$ & $0.20 \pm 0.12^{\mathrm{a}}$ & $1.00 \pm 0.00^{\mathrm{a}}$ \\
\hline $\begin{array}{l}\mathrm{MS}+1.0 \mathrm{mg} / \mathrm{L} \mathrm{NAA} \\
+1.0 \mathrm{mg} / \mathrm{L} \mathrm{IBA}\end{array}$ & $2.40 \pm 0.51^{\mathrm{bc}}$ & $2.00 \pm 0.00^{\mathrm{c}}$ & $1.40 \pm 0.25^{\mathrm{a}}$ \\
\hline $\mathrm{MS}+3.0 \mathrm{mg} / \mathrm{L} \mathrm{IBA}$ & $3.60 \pm 0.60^{\mathrm{c}}$ & $2.22 \pm 0.46^{\mathrm{c}}$ & $1.00 \pm 0.00^{\mathrm{a}}$ \\
\hline
\end{tabular}

${ }^{1}$ Values represent means \pm standard error (SE), $\mathrm{N}=5 .{ }^{2}$ Mean values followed by same letter(s) within a column are not significantly different by Tukey HSD test at $\mathrm{P} \leq 0.05$.

After 5 weeks, a maximum frequency of $100 \%$ in vitro roots formation with the highest number of roots per culture $(3.60 \pm 0.60)$ was observed on $\mathrm{MS}+3.0 \mathrm{mg} / \mathrm{L}$ IBA. The number of roots increased $(6.00 \pm 0.55)$ after 12 weeks. Increased concentrations of IBA not only resulted in higher rate of rooting response, but also to the number of roots per culture, its length as well as the morphology of the roots established. The established roots were thick and generally yellowish green in color (Fig. 5a).
TABLE IV

PGRS RESPONSE ON IN VITRO ROOTING OF IN VITRO PLANTLETS ObTAined From BASAl Stem EXPLANT of SugAR PALM By Direct ORGANOGENESIS AFTER 12 WEEKS OF CULTURE

\begin{tabular}{|l|c|c|c|}
\hline $\begin{array}{l}\text { MS medium } \\
\text { composition(s) }\end{array}$ & $\begin{array}{c}\text { Root per } \\
\text { culture }\end{array}$ & $\begin{array}{c}\text { Root length } \\
\text { per culture }\end{array}$ & $\begin{array}{c}\text { Leaf per } \\
\text { culture }\end{array}$ \\
\hline MS0 & $1.00 \pm 0.32^{\mathrm{a}}$ & $0.60 \pm 0.19^{\mathrm{a}}$ & $1.20 \pm 0.20^{\mathrm{a}}$ \\
\hline $\mathrm{MS}+1.0 \mathrm{mg} / \mathrm{L} \mathrm{NAA}$ & $3.00 \pm 0.55^{\mathrm{b}}$ & $2.40 \pm 0.43^{\mathrm{ab}}$ & $1.40 \pm 0.25^{\mathrm{a}}$ \\
\hline $\mathrm{MS}+1.0 \mathrm{mg} / \mathrm{L} \mathrm{IAA}$ & $1.60 \pm 0.51^{\mathrm{ab}}$ & $1.30 \pm 0.49^{\mathrm{a}}$ & $1.20 \pm 0.20^{\mathrm{a}}$ \\
\hline $\begin{array}{l}\mathrm{MS}+1.0 \mathrm{mg} / \mathrm{L} \mathrm{NAA} \\
+1.0 \mathrm{mg} / \mathrm{L} \mathrm{IBA}\end{array}$ & $5.00 \pm 0.32^{\mathrm{c}}$ & $3.50 \pm 0.45^{\mathrm{bc}}$ & $1.80 \pm 0.20^{\mathrm{a}}$ \\
\hline $\mathrm{MS}+3.0 \mathrm{mg} / \mathrm{L} \mathrm{IBA}$ & $6.00 \pm 0.55^{\mathrm{c}}$ & $4.40 \pm 0.58^{\mathrm{c}}$ & $2.20 \pm 0.37^{\mathrm{a}}$ \\
\hline
\end{tabular}

${ }^{1}$ Values represent means \pm standard error (SE). $\mathrm{N}=5 .{ }^{2}$ Mean values followed by the same leeter9s 0 within a column are not significantly different by Tukey HSD test at $\mathrm{P} \leq 0.05$.

Well-developed roots in term of length, root tissue density, stem girth and mass of root tips within a plant is a good indicator of acclimatization as it allows plants to regulate the nutrient and water uptake to the surrounding environment [21]. The efficiency of IBA for the induction of roots have been previously reported in other plant species which included mangrove [22], date palm [23], and olive [24]. Meanwhile, a contradictory finding was reported in papaya where the increasing compositions of IBA was affirmed to reduce rooting frequency combined with the growth of unwanted callus [25]. MS medium without the addition of PGRs (control) failed to induce root formation within 5 weeks of culture, but slowly responded after 12 weeks, giving $40 \%$ root induction with the number of roots and length at $1.00 \pm 0.32$ and $0.60 \pm 0.19$ respectively. Each treatment produced a general number of $1.00 \pm 0.00$ 2.20 \pm 0.37 leaf per culture.

TABLE V

Acclimatization of Clonal Sugar Palm Plantlets Under DIFFERENT LIGHT INTENSITIES AFTER 4 MONTHS

\begin{tabular}{|c|c|c|c|c|c|}
\hline 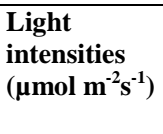 & $\begin{array}{c}\text { Plantlet } \\
\text { survival } \\
\text { frequency } \\
(\%)\end{array}$ & $\begin{array}{c}\text { Plant } \\
\text { height } \\
(\mathbf{c m})\end{array}$ & $\begin{array}{l}\text { Stem } \\
\text { girth } \\
(\mathrm{cm})\end{array}$ & $\begin{array}{c}\text { Number } \\
\text { of leaf }\end{array}$ & $\begin{array}{r}\text { Leaf } \\
\text { width } \\
(\mathrm{cm})\end{array}$ \\
\hline$<50$ & 80 & $\begin{array}{l}8.60 \pm \\
0.68^{\mathrm{a}}\end{array}$ & $\begin{array}{l}0.38 \pm \\
0.04^{\mathrm{a}}\end{array}$ & $\begin{array}{l}2.40 \pm \\
0.25^{\mathrm{a}}\end{array}$ & $\begin{array}{l}2.32 \pm \\
0.15^{\mathrm{a}}\end{array}$ \\
\hline $50-100$ & 70 & $\begin{array}{c}13.00 \pm \\
1.52^{\mathrm{a}}\end{array}$ & $\begin{array}{l}0.48 \pm \\
0.04^{\mathrm{a}}\end{array}$ & $\begin{array}{l}3.40 \pm \\
0.25^{\mathrm{a}}\end{array}$ & $\begin{array}{l}2.16 \pm \\
0.14^{\mathrm{a}}\end{array}$ \\
\hline$>100$ & 40 & $\begin{array}{l}8.60 \pm \\
2.44^{\mathrm{a}}\end{array}$ & $\begin{array}{l}0.30 \pm \\
0.08^{\mathrm{a}}\end{array}$ & $\begin{array}{c}2.00 \pm \\
0.55^{\mathrm{a}}\end{array}$ & $\begin{array}{l}1.62 \pm \\
0.42^{\mathrm{a}}\end{array}$ \\
\hline
\end{tabular}

${ }^{1}$ Values represent means \pm standard error (SE), $\mathrm{N}=5 .{ }^{2}$ Mean values followed by same letter(s) are not significantly different by Tukey HSD test at $\mathrm{P} \leq$ 0.05 .

\section{Acclimatization of Clonal Sugar Palm Seedlings under Different Light Intensities}

The hardening and acclimatization phases are the most crucial steps in the micropropagation protocol of sugar palm. The acclimatization of micro propagated plants is rather complicated and peculiar depending to the crop type [25]. Success in micropropagation required the plantlets that have been raised within a high humidity condition to withstand the environmental changes, become autotrophic and develop under moderate or low humidity conditions. Meanwhile, light intensity is one of the four crucial factors other than nutrients, humidity and temperature which determine optimum result during acclimatization. In the present study, successful acclimatization of clonal sugar palm seedlings 
and their growth development under different light intensities were determined (Table V).

Hardening of in vitro plantlets in potting mixture containing sterile soil: peat moss: perlite $(2: 2: 1)$ under high humidity condition resulted in $90 \%$ rate of survival after 2 months of transfer (Fig. 5c). The high survival rate may be due to the healthy and well-developed root system and the composition of planting medium. Upon transplanting the clonal seedlings into new pots with regular garden soil and maintained under different light intensities, an optimum $80 \%$ rate of survival was obtained at $<50 \mu \mathrm{mol} \mathrm{m} \mathrm{m}^{-2} \mathrm{~s}^{-1}$ after 4 months of acclimatization. The plant height, stem girth, leaf number and leaf width were recorded at $8.60 \pm 0.68 \mathrm{~cm}$, $0.38 \pm 0.04 \mathrm{~cm}, 2.40 \pm 0.25$ and $2.32 \pm 0.15 \mathrm{~cm}$ respectively. Acclimatized clonal seedlings were green, but some leaves were necrotic and deteriorated.

However, the optimum plant growth development was observed on the clonal seedlings being acclimatized under the light intensity of $50-100 \mu \mathrm{mol} \mathrm{m} \mathrm{m}^{-2}$ with the plant height of $13.00 \pm 1.52 \mathrm{~cm}$. The stem girth, leaf number per culture and leaf width were recorded at $0.48 \pm 0.04 \mathrm{~cm}$, $3.40 \pm 0.25$ and $2.16 \pm 0.14 \mathrm{~cm}$ respectively. Clonal seedlings were healthy, green colored and new leaves were established (Fig. 5d). Uprooted clonal seedlings maintained under the light intensity also showed a healthy, strong and vigorous root formation (Fig. 5e). In the meantime, clonal seedlings acclimatized under high light intensity $\left(>100 \mu \mathrm{mol} \mathrm{m} \mathrm{m}^{-2}\right)$ gave the lowest rate of plantlets survived (40\%).
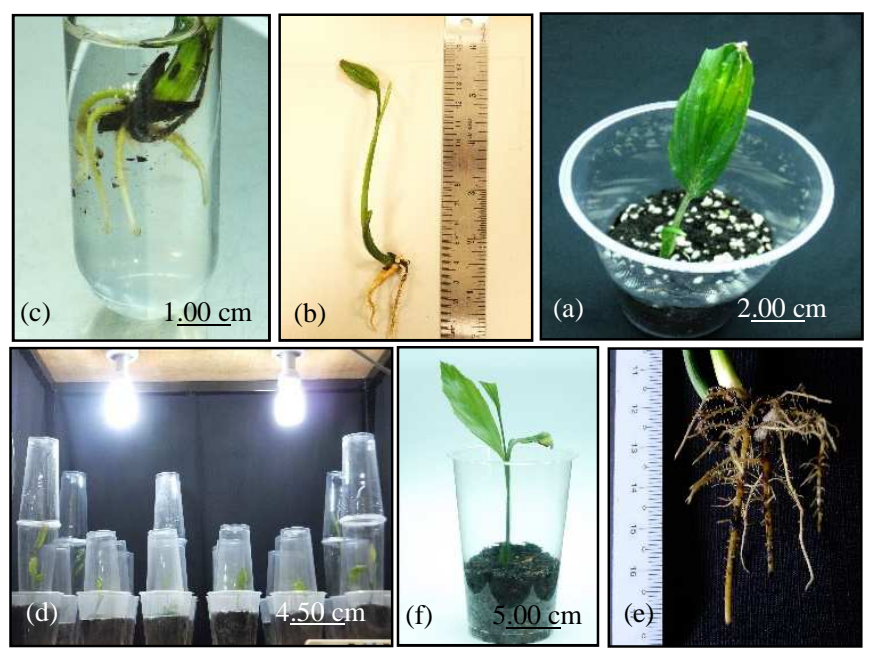

Fig. 5 (a) Optimum in vitro rooting of clonal shoot regenerates of sugar palm from basal stem explant on $\mathrm{MS}+2.0 \mathrm{mg} / \mathrm{L}$ IBA. (b) In vitro clonal plantlets with well-developed root system ready for hardening. (c) Hardening of clonal plantlets in plastic pots containing sterile mixture of soil: peat moss: perlite (2: 2:1) after 2 months of transfer. (d) Incubation of clonal seedlings transplanted to regular garden soil under $50-100 \mu \mathrm{molm}^{-2} \mathrm{~s}^{-}$ ${ }^{1}$. (e) In vitro plantlets after 2 months of acclimatization under 50-100 $\mu \mathrm{mol}$ $\mathrm{m}^{-2} \mathrm{~s}^{-1}$ light intensity. (f) Vigorous and strong root formation of sugar palm's clonal seedlings acclimatized under greenhouse condition.

There is no significant difference between the growth parameters of clonal seedlings incubated under $>50 \mu \mathrm{mol} \mathrm{m}$ ${ }^{2} \mathrm{~s}^{-1}$ but with a different reason. Leaves produced are thicker with smaller width and burnt marks were presented on some leaves leading to wilting and dying of clonal seedlings. It was explained that these outcomes are frequent mainly when it involves high light intensities. This process cannot be rushed without a severe reaction by the plants which may range from partial leaf drop to death [26].

\section{CONCLUSIONS}

Our results showed that sugar palm trees could be clonally propagated by direct organogenesis using immature zygotic embryo and basal stem segment obtained from in vitro seedling as explants. Organogenesis response of both explants was highly influenced by the type and concentrations of PGRs used. MS medium devoid of PGRs gave no response for shoot regeneration on both explants. Shoot multiplication failed on all treatments tested except for immature zygotic embryo explant treated with $\mathrm{AgNO}_{3}$. MS culture medium incorporated with $3.0 \mathrm{mg} / \mathrm{L}$ IBA favored a vigorous rooting performance of sugar palm. Optimized acclimatization of clonal seedlings was obtained under $50-100 \mu \mathrm{mol} \mathrm{m} \mathrm{m}^{-2}$ light intensity. Further research is recommended to obtain an efficient shoot multiplication of sugar palm by direct organogenesis.

\section{ACKNOWLEDGMENT}

The research was financially supported by Mybrain15 scholarship, Ministry of Higher Education Malaysia and Research Management Institute, Universiti Teknologi MARA (UiTM) Shah Alam, Selangor, Malaysia.

\section{REFERENCES}

[1] M.G. Simpson, Ed., Plant Systematics, 2nd ed. USA: Elsevier, 2010.

[2] Z. Wu, P.H. Raven, and D. Hong, Eds., Flora of China. Beijing: Science Press, 2010.

[3] P. Arsad, R. Sukor, W.I. WZ, N.A. Mustapha, and M.H. AS, "Effects of Enzymatic Treatment on Physicochemical Properties of Sugar Palm Fruit Juice," International Journal on Advanced Science, Engineering and Information Technology, vol. 5, iss. 5, pp. 308-312, 2015.

[4] H.Y. Sastra, J.P. Siregar, S.M. Sapuan, and M.M. Hamdan, "Tensile properties of Arenga pinnata fiber-reinforced epoxy composites," Polym Plastics Technol Eng., vol. 45 (1-3), pp. 149-155, 2006.

[5] R. Putih, B. Satria, and R. Thaib, "Vegetative propagation effort of enau (Arenga pinnata (Wurmb) Merr.) by shoot regeneration in vitro," Stigma, vol. 11, iss. 3, pp. 208-212, 2003.

[6] M.G. Devi, A. Purwito, and A. Husni, "Globular Embryo Induction of sugar palm (Arenga pinnata (Wurmb) Merr.)," Int. J. Bio. Sc., Bio Chem., Bio Inf., vol. 4, iss. 1, pp. 60-66, 2014.

[7] M.P. Singh, and S. Kumar, Eds., Plant Tissue Culture. New Delhi: APH Publishing Corporation, 2009.

[8] A. Hussain, I.A. Qarshi, H. Nazir, and I. Ullah, Plant tissue culture: current status and opportunities, in A. Leva, and M.R. L. Rinaldi, Eds., Recent Advances in Plant In vitro Culture. USA: InTech, 2012.

[9] A. Romeida and D.W. Ganefianti, "Embryogenic Callus Induction of Pencil Orchid (Papilionanthe hookeriana Rchb. f.) Through In Vitro Culture," International Journal on Advanced Science, Engineering and Information Technology, vol. 6, iss. 2, pp. 196-200, 2016.

[10] A. C. Beyl, PGRs and their use in micropropagation, in R.N. Trigiano, and D.J. Gray, Eds., Plant tissue culture, Development and Biotechnology. USA: CRC Press, 2011.

[11] M. A. Arsyad, "Embryo rescue through in vitro technique and production of sugar palm (Arenga pinnata (Wurmb) Merr.) seedlings," M. thesis, School of Graduate studies, IPB, Bogor, Indonesia, 2013.

[12] M. Nazatul-Asikin, A. Awal, A. Mohd Yusoff, and A. Shamsiah, "Embryogenic callus induction of Arenga pinnata Wurmb. Merr (sugar palm) from basal stem explant," International Journal of Advances in Agricultural and Environmental Engineering, vol. 3, iss. 1, pp. 106-109, 2016. 
[13] T. Murashige, and F. Skoog, "A revised medium for rapid growth and bioassays with tobacco tissue cultures," Physiologia Plantatrum, vol. 15, pp. 473-497, 1962.

[14] S. Bekheet, "Direct organogenesis of date palm (Phoenix dactylifera L.) for propagation of true-to-type plants," Scientia Agriculturae, vol. 4, iss. 3, pp. 85-92, 2013.

[15] M. S. Shekhawat, N. Kannan, M. Manokari, and C.P. Ravindran, "In vitro regeneration of shoots and ex vitro rooting of an important medicinal plant Passifflora foetida L. through nodal segment cultures," Journal of Genetic Engineering and Biotechnology, vol. 13, iss. 2, pp. 209-214, 2015.

[16] Z. Ab Rahman, F.L.I. Kamaruddin, A.N. Othman, C.R. Che Mohd Zain, S.N.A. Sheikh Ghadzi, and S. Sreeramanan, "In vitro regeneration of Curcuma caesia plantlets from basal part and via somatic embryogenesis," Advances in Bioscience and Biotechnology, vol. 5, pp.363-372, 2014.

[17] J. Sun, P.D. Lei, Z. Z. Zhang, G.H. Shi, Z.J. Tang, S.Y. Zhu, C. J. Jiang, and X. C. Wan, "Shoot basal ends as novel explants for in vitro plantlet regeneration in an elite clone of tea," The Journal of Horticultural Science and Biotechnology, vol. 87, iss. 1, 2012.

[18] A. Awal, R.M. Taha, and N. A. Hasbullah, "Somatic embryogenesis in Begonia x hiemali Fotsch. in vitro," ISHS Acta Horticulturae, vol. $829,2008$.

[19] R. H. Smith, Ed., Plant Tissue Culture: Techniques and Experiments. USA: Elsivier, Academic Press, 2013

[20] A. Awal, A. A. B. Ali Ahmed, R. M. Taha, J. S. Yaacob, and S. Mohajer, "Effect of adenine, sucrose and plant growth regulators on the indirect organogenesis and on in vitro flowering in Begonia $\mathrm{x}$ hiemalis Fostch," Australian Journal of Crop Science, vol 7, iss. 5, pp. 691-698, 2013.
[21] I. Ostonen, K. Rosenvald, H. Helmisaari, D. Godbold, K. Parts, V. Uri, and K. LÕhmus, "Morphological plasticity of ectomycorrhizal short roots in Betula sp and Picea abies forests across climate and forest succession gradients: its role in changing environments," Frontiers in Plant Science, vol. 4, pp. 191- 203, 2013.

[22] A. A. Alatar, M. Faisal, A.K. Hegazy, H.A. Alwathani, and M. K. Okla, "Clonal in vitro multiplication of grey mangrove and assessment of genetic fidelity using single primer amplification reaction (SPAR) methods," Biotechnology \& Biotechnological Equipment, vol. 29, iss. 6, pp. 1069-1074, 2015.

[23] R.S. Darwesh, E. A. Madbolly, and E. G. Gadalla, "Impact of Indole Butyric Acid and Paclobutrazol on rooting of date palm (Phoenix dactylifera L.) off-shoots cultivar Zaghloul,” Horticultural Science \& Ornamental Plants, vol. 5, iss. 3, pp. 145-150, 2013.

[24] G. Khajehpour, V. Jam'eizadeh, and N. Khajehpour, "Effect of different concentrations of IBA (Indullebutyric acid) hormone and cutting season on the rooting of the cuttings of olive (Olea europae var Manzanilla)," International Journal of Advanced Biological and Biomedical Research, vol. 2, iss. 12, pp. 2920 - 2924, 2014.

[25] A. Setargie, F. Mekbib, and E. Abraha, "In vitro propagation of papaya (Carica papaya L.)," World Journal of Agricultural Sciences, vol. 11, iss. 2, pp. 84-88, 2015.

[26] R. H. Zimmerman, Micropropagation of woody plants: post tissue culture aspects, in R. Rodríguez, R. S. Tamés, D.J. Durzan, Eds., Plant Aging: Basic and Applied Approaches. New York, London: Plenum Press, 2012. 